\title{
Reducing the Impact of Forest Harvesting on the Vancouver Island Tourism Industry
}

\author{
by Kyle W. Hilsendager ${ }^{1}$, Howard W. Harshaw ${ }^{2}$ and Robert A. Kozak ${ }^{1}$
}

\begin{abstract}
British Columbia forests have traditionally been managed for timber production. However, the increasing importance of nature-based tourism within the province means that forests also have significant value as a tourism resource. This can lead to conflicts between the forestry and tourism industries. This article examines tourism and forestry interests on Vancouver Island and discusses ways that forests could be managed to reduce negative impacts to the tourism industry. Eighteen semi-structured interviews were conducted with forestry and tourism industry professionals on Vancouver Island and elsewhere in British Columbia. Findings suggest that visual impacts associated with forestry can negatively impact tourism. It also appears that forestry receives a much higher priority than tourism when it comes to forest management, despite the vital importance of the tourism industry to the Vancouver Island economy. Displeasure over the lack of communication requirements between the forest industry and other stakeholders was also documented. The implementation of formal agreements between the two industries may potentially reduce conflicts between these two industries on Vancouver Island. Identification and special management of highly valuable tourism areas may also provide benefits to the Vancouver Island tourism industry.
\end{abstract}

Keywords: forestry, nature-based tourism, conflict, land use

\section{RÉSUMÉ}

Les forêts de la Colombie-Britannique ont été traditionnellement aménagées pour produire du bois. Cependant, limportance grandissante du tourisme en milieu naturel dans la province signifie que les forêts ont également une valeur importante comme ressource touristique. Cela peut entraîner des conflits entre l'industrie forestière et l'industrie touristique. Cet article s'intéresse aux intérêts forestiers et touristiques de lîle de Vancouver et aux façons d’aménager les forêts pour minimiser les effets négatifs sur les activités touristiques. On a effectué dix-huit entrevues semi-structurées auprès de professionnels de l'industrie forestière et du tourisme sur l'île de Vancouver et ailleurs en Colombie-Britannique. Les résultats laissent entendre que les impacts visuels associés à la foresterie peuvent avoir des effets négatifs sur le tourisme. Il appert de plus que la foresterie jouit d'un niveau de priorité bien plus élevé que le tourisme en matière d’aménagement forestier, malgré l'importance vitale de l'industrie touristique au sein de léconomie de l'île de Vancouver. Le manque de communication directe entre l'industrie forestière et les autres intervenants serait aussi source de mécontentement. La conclusion d'ententes formelles entre les deux industries permettrait sans doute d'atténuer les conflits qui les opposent sur l'île de Vancouver. L'identification de secteurs à forte valeur touristique et le fait d’en faire un aménagement particulier pourraient aussi favoriser l'industrie touristique de l'île de Vancouver.

Mots clés : foresterie, tourisme en milieu naturel, conflit, utilisation du territoire

\section{Introduction}

In many places, the forest industry faces significant opposition from some members of the public. Although timber production is viewed as a legitimate use of forest resources by most people, there also seems to be a desire for a better balance between commodity and non-commodity uses in forests (Shindler et al. 2002). Forest management issues that often lead to negative public perceptions include clear-cutting, the use of herbicides (Wagner et al. 1998), and the visual effects of landscape alteration (Kearney 2001). The visual effects of forestry on the landscape seem to be a particularly important issue in determining public acceptance of management practices. For instance, it was the visual effects of clear-cutting that was the primary cause of the Bitterroot and Monongahela
National Forest controversies in the United States during the early 1970s (McCool et al. 1986) and the 1990s Clayoquot Sound conflict in British Columbia, Canada (Wilson 1998). Scenes of clear-cuts are often used by environmental advocacy groups to illustrate forest destruction and gain support for stricter management regulations (Kearney 2001).

Public perception issues can have clear negative impacts on forestry if they lead to campaigns that affect industry profitability. Although much criticism originates locally, there are examples of forest management issues that have received national (Buckman 2008) and international (Wilson 1998, Magnusson and Shaw 2002, Environmental News Network 2006) attention. Public perception issues that receive widespread attention could also negatively impact other industries

\footnotetext{
${ }^{1}$ Faculty of Forestry, University of British Columbia, Vancouver, British Columbia; ${ }^{\star}$ Corresponding author: kyle.hilsendager@viu.ca

${ }^{2}$ Faculty of Physical Education and Recreation, University of Alberta, Edmonton, Alberta
} 
that rely on forested landscapes, such as tourism. This is especially true for regions that promote natural landscapes to attract visitors (McKercher 1992). Because these places rely on natural landscapes to attract tourists, they may be particularly vulnerable to the negative perceptions that are often associated with industrial forestry impacts. This is especially true if forest management conflicts receive media attention in markets that are an important source for nature-based tourists.

Nature-based tourism in rural and peripheral areas has seen steady growth throughout many parts of the world and now accounts for a significant proportion of tourism experiences (Tyrvainen et al. 2014). In places where this industry makes significant contributions to local economies, it is important to ensure that the resources upon which naturebased tourism relies are not compromised by other interests. Because timber harvesting can have an impact on visual landscapes and the natural environment, it also has the potential to negatively affect nature-based tourism. Vancouver Island, on the west coast of British Columbia, Canada, supports active forestry and tourism industries, which play important roles in local economies throughout the Island. However, forest practices have the potential to negatively impact the Vancouver Island tourism industry because of its reliance on natural landscapes to attract visitors. Using qualitative approaches, this article aims to uncover ways in which forests can be managed to help minimize the negative impact that forestry can have on the tourism industry on Vancouver Island. A set of management recommendations is also developed to help guide other jurisdictions that may be dealing with forestry and tourism related land-use conflicts.

\section{Background}

\section{Forestry and Tourism}

Results from past studies suggest that environmental consequences play an important role in the formation of public acceptability judgements about forest management (Ribe 2006, Ford et al. 2012). These judgements appear to be the environmental consequences of forestry influenced by the visual quality of landscapes (Ford et al. 2012). Many people associate visual quality with environmental quality, despite the fact that one is not necessarily an indication of the other. When judging the visual quality of landscapes, people tend to be more accepting of natural appearing conditions and much less accepting of highly modified landscapes (Picard and Sheppard 2001). It has also been shown that the public prefer landscapes that exhibit intact patterns of forest cover over more obvious forest openings that result when clear-cutting is employed as a harvesting method (Ribe 2004). Research conducted in British Columbia has also demonstrated public preferences for natural looking landscapes compared to those that appear to have been modified by forestry (British Columbia Ministry of Forests and Range 2006). These studies suggest that people tend to be more accepting of forestry if the environmental consequences are minimized and that these acceptability judgements are often a reflection of the perceived visual quality of natural landscapes.

The extent to which visual settings influence landscape perceptions has been shown to vary between tourists and residents. In research conducted in British Columbia, visitors to a coastal wilderness tourism resort had a lower level of acceptance for landscape alteration than was exhibited among British Columbia residents in other perceptual studies (British Columbia Ministry of Forests 2003). In another study, the British Columbia Ministry of Forests and Range (2006) examined the differences between tourists and local residents using the same photographic scenes. In this research, tourists were also less accepting of forest alteration than residents. Hilsendager (2014) has also documented negative perceptions of forest industry impacts amongst tourists at various sites in Vancouver Island and Tasmania, Australia. These studies appear to suggest that insensitive forest practices have the potential to negatively impact the tourism industry in places that promote natural landscapes.

Concerns about the impact that the forest industry may have upon nature-based tourism experiences have been expressed by tourism stakeholders in various places. For example, a proposal to develop the Bell Bay Pulp Mill in Tasmania sparked significant concern from the tourism industry. In a survey conducted by the Tourism Industry Council of Tasmania (2007), 58\% of Tasmanian tourism operators thought that the proposed pulp mill would have a negative effect on the Tasmanian brand. In Canada, Hunt et al. (2000) revealed that many resource-based tourism operators in Ontario believed that forest harvesting operations have a high likelihood of negatively impacting their tourism operations in remote areas. In the Clayoquot Sound area, much of the local opposition directed at forestry in the late 1980s and early 1990s was initiated by local tourism stakeholders (Wilson 1998). These examples demonstrate the concern that many tourism stakeholders have about the potential impacts that forestry could have upon their product and suggest that decision-makers should carefully consider potential implications of resource development near areas that rely on the natural environment to attract tourists.

\section{Vancouver Island}

On Vancouver Island, the majority of the forest landbase is publicly owned and managed by the Provincial Government. Throughout British Columbia, the Ministry of Forests, Lands and Natural Resource Operations is responsible for authorizing the use of publicly owned lands for activities that include timber harvesting (British Columbia Ministry of Forests, Lands \& Natural Resource Operations 2012) and commercial tourism (British Columbia Ministry of Forests, Lands \& Natural Resource Operations 2015). Private companies are given the right to conduct activities on publicly owned lands through tenure agreements. These agreements are legally binding and provide tenure holders (i.e., licensees) with certain rights to use public forests for a specific period of time. In return, licensees are required to meet government land use objectives and comply with relevant legislation governing the use of these areas (British Columbia Ministry of Forests, Lands \& Natural Resource Operations 2012).

With a population of roughly 750000 , Vancouver Island relies heavily on the tourism to create employment. This region is home to most tourism-related businesses in British Columbia outside of the Vancouver region (Destination British Columbia 2014). When surveyed about their primary motivations for visiting Vancouver Island, 28\% of all leisure visitors identified 'scenic beauty' as their primary motivation (Tourism Vancouver Island 2008), which highlights the 
important role that natural landscapes play in attracting tourists to the region. In 2012, the tourism industry contributed approximately $\$ 7.6$ billion to the British Columbia GDP (BC Stats 2014a) and provided nearly 17000 Vancouver Island residents with employment (BC Stats 2014b).

The natural settings of Vancouver Island provide visitors with a variety of different front- and back-country recreation opportunities. One of the most well-known outdoor attractions in the region is the West Coast Trail, which provides hikers with a challenging multi-day trek through the temperate rainforest on the Pacific Coast. There are also numerous shorter hikes available, as well as trails that can accommodate other activities such as cycling and horseback riding. Many activities that take place on water are also popular with tourists. Saltwater fishing is an activity that attracts many visitors due to the high number of charter companies available and the diversity of species that can be caught in the waters surrounding Vancouver Island. Other water-based activities include kayaking, canoeing, sailing, diving, and whale watching. In addition to the many outdoor activities available, visitors are also attracted by the numerous charismatic wildlife species that inhabit the region including bears, eagles, cougars, and elk (Tourism Vancouver Island 2011). With such a range of outdoor recreation activities available it is easy to see why the maintenance of environmental quality is so important for Vancouver Island's tourism industry.

Forestry is also a significant component of the British Columbia economy. In 2013, the industry contributed $\$ 1.8$ billion toward the provincial GDP (BC Stats 2015a). The industry also provides important employment opportunities to Vancouver Island residents. In 2007, the industry employed 6500 people living in the Vancouver Island/Coast region. This number dropped to 2500 individuals during the 2008-2009 economic downturn but has since rebounded to about 4500 jobs as of 2014. Employment numbers in forestry tend to vary according to region, with the North Island District being most reliant upon the industry (BC Stats 2015b).

\section{Regulatory Framework}

In the early 1990s, the Commission on Resources and Environment (CORE) was created with the purpose of improving resource management, while giving stakeholders a voice in regional land-use decision-making processes (Hanna et al. 2008). The Vancouver Island Land Use Plan that was created as part of CORE does have certain provisions that help protect or enhance tourism and recreation values. For example, Special Management Zones were established in certain areas where scenic, recreation, and other natural values were given management priority. The protection of these types of values has direct benefits to the nature-based tourism industry due to its reliance on scenery, nature, and outdoor recreation opportunities. A number of new protected areas were also created as a result of the Vancouver Island Land Use Plan. The establishment of these new parks helped to further enhance the scenic and natural values of Vancouver Island (British Columbia 2000), strengthening nature-based tourism values.

In July 1994, the Forest Practices Code was enacted (Wilson 1998). Its introduction was designed to help address a number of issues associated with forest management including poor stewardship, inadequate monitoring and enforcement, and weak penalties for violators (Malkinson 2011). Some of the defining features of the Forest Practices Code included an emphasis on improved environmental protection and forest practices, as well as the introduction of stiff enforcement penalties. When the Code was introduced, the Minister of Forests stated that it would ensure that ecological requirements would drive forest management decision-making (Cashore et al. 2001). Like the Vancouver Island Land Use Plan, it seems as though the environmental provisions within the Forest Practices Code would have also provided benefits to the nature-based tourism industry.

Despite the environmental benefits associated with the Forest Practices Code, certain problems were also identified. For example, the British Columbia Forest Practices Board (2006) suggested that the code was too prescriptive and prevented innovation from occurring within the forest industry. The Forest Practices Code was also criticized for placing additional administrative burden upon government staff (Reader 2006), as well as increasing financial costs to both government and industry. To help overcome some of these issues, the Forest and Range Practices Act was introduced in 2004 to replace the Forest Practices Code (Malkinson 2011).

Often described as a 'results-based' approach to forest management regulation (British Columbia Forest Practices Board 2006), the Forest and Range Practices Act currently governs forest management within the Province of British Columbia. This approach shifts the focus from forest management processes to the achievement of desired results. This allows tenure holders to design their own regulatory regimes that are tenure-specific, provided that they meet the specified government management objectives (Reader 2006). These objectives can relate to a wide range of forest resource values and may consider things like timber, outdoor recreation, soils, community watersheds, cultural heritage resources, and visual quality (British Columbia Forest Practices Board 2006). In British Columbia, visual landscape inventories identify and record areas that are considered to be visually sensitive. Those responsible for forest planning then use this information to establish visual quality objectives that reflect the desired level of visual quality for the area. Once established, operational practices are expected to be carried out in a way that achieves the stated objectives (British Columbia Ministry of Forests 2001).

\section{Methods}

This research sought insight into actual conflicts that have occurred between forestry and tourism on Vancouver Island, while uncovering measures that could be used to help reduce the impact that forestry can have on the tourism industry. To understand this issue, data was collected through 18 semistructured interviews with tourism and forestry professionals from Vancouver Island and elsewhere in British Columbia. Interview participants included business owners/managers, government employees, and representatives from industry organizations. These individuals were selected because of their unique knowledge and experience in the fields of either forestry or tourism. To help ensure that a range of opinions was represented, a diverse group of interview participants was chosen from a total of 13 different organizations. There were a higher number of tourism-affiliated interview participants (11) than forest industry participants (7). This was because saturation was achieved much earlier with forest industry 
affiliated interviewees. Those working for forest management organizations showed a tendency to answer many interview questions in a similar way, whereas the opinions of tourism operators were highly dependent on their individual contexts, experiences, and opinions. Therefore, more interviews were required with tourism affiliated interviewees.

Interview questions were designed with the purpose of learning about actual tourism and forestry conflicts, as well as measures that can be taken to alleviate these situations. Therefore, these topics were used to help guide the analysis. All interviews were digitally recorded and transcribed to a text document. Data was analyzed with QSR NVivo version 10 software using a thematic analysis approach. A number of dominant themes emerged in the data, which were then used to guide the analysis. Interviewee statements were continually assessed against legislation and policy documents (i.e., Forest and Range Practices Act, Land Act) to help ensure rigour and reliability of the analysis.

One of the benefits associated with the interview method is the ability that it gives researchers to follow up on certain questions by asking for more detail (Kraus and Allen, 1997). Therefore, many of the interviews differed in terms of some of the topics that were discussed and the depth that these discussions went into. However, they were all guided by a predetermined script containing questions that could be categorized into three broad topics. Respondents were first asked a series of introductory questions relating to occupational history and length of time in their current position. The purpose of this was to provide an indication of participants' industry experience and familiarity with issues being discussed. The second set of questions asked about ways in which forestry can impact tourism values on Vancouver Island. The final set of questions was designed to uncover measures that could be used to reduce potential conflicts and foster positive relationships between forestry and tourism on Vancouver Island.

\section{Results}

In regions where nature-based tourism and forestry both make important contributions to local economies, there are many situations where these two industries interact. The following sections discuss some of the ways in which forestry can affect tourism. Possible solutions that could be used to help minimize potential conflicts are discussed in the context of forestry-tourism interactions on Vancouver Island, British Columbia. Number and letter combinations found in brackets after interview quotes are used to distinguish interview participants from one another. Those identified with ' $T$ ' were affiliated with the tourism industry, while those identified with ' $\mathrm{F}$ ' were affiliated with the forest industry.

\section{Positive Impacts}

It is important to note that the forest industry in Vancouver Island does provide certain benefits to the nature-based tourism industry, some of which were identified in the semistructured interviews. For example, forestry helps to provide access to remote places for many nature-based tourists. Some roads that were originally constructed for logging provide visitors with opportunities to participate in activities such as wildlife viewing, fishing, and hiking. Two of the participants who were affiliated with the tourism industry explicitly noted these benefits, with one of these individuals stating:
There is a lot of tourism products in the province that probably wouldn't exist in the way that they do right now without the road access that has been created by the forest industry, there is no doubt. So, that is really a positive thing (T5).

Although this is not the case for all types of operations, forestry often provides extra revenues for tourism businesses. In many regional areas, forest industry workers utilize tourism related services, such as accommodation and food establishments. According to one of the tourism affiliated interview participants, a large proportion of revenue for these types of businesses can actually come from workers who are working away from home. This is especially true during the low season for tourism (e.g., winter) and for more remote areas.

And we know that the logging camp kind of keeps us alive in the wintertime and they are part of the community. So we just sort of live with each other (T2).

\section{Forest Management Concerns}

Despite the benefits identified, some of the interviewees within the tourism industry view forestry as a detriment to their business because they have experienced situations where forestry has negatively impacted the nature-based tourism industry. The most obvious impacts associated with forestry relate to the visual effects that harvesting can have on scenic landscapes. This was mentioned by interviewees from both tourism and forestry. The potential impacts that some forest practices can have on a tourism product that relies on natural attractions was highlighted by one interviewee in the tourism industry who explained:

Our product involves selling an experience to people who travel to British Columbia to experience that wilderness and nature, natural values that $B C$ has historically had a reputation for. So, industrial activity and the visual impact of clear-cuts diminishes that wilderness value in the eyes of the tourists, which, in turn, lowers the value of our tours and makes them less marketable, less saleable, and lowers the quality of experience for people (T4).

In addition to the visual impacts associated with forestry, other aspects of land-use were identified as having the potential to negatively impact upon the tourism industry. Landscape-scale alterations over large areas were mentioned as a concern in regions of Vancouver Island that are considered to have exceptional tourism value. While discussing the impact that numerous tourism businesses are facing in their region, one tourism-affiliated interviewee stated:

It seems like the more you talk about the issue with people, the more you hear them say, 'oh, my camp is dealing with impending forestry activity in the channel.' It just never seems to end (T3).

The previous quote suggests that some nature-based tourism businesses struggle in landscapes that are dominated by forest industry impacts. However, a large number of nature-based tourism operators have no choice but to operate in these highly altered landscapes. This is because there are a finite number of commercial recreation opportunities within protected areas. However, few areas outside of protected areas are specifically managed for the maintenance of tourism values. Instead, most areas of Vancouver Island are managed primarily for timber production (British Columbia Ministry of 
Agriculture and Lands, 2008). The lack of areas accessible for commercial nature-based tourism opportunities was highlighted by one forest industry affiliated interviewee who said:

We have a very extensive parks and recreation system on Vancouver Island, where we, as members of the public, can go and enjoy that pristine wilderness setting, the trail networks, the campground networks. But tourism operators cannot facilitate that experience for us because they are unable to get tenure. And so, they are locked out looking in. And because they cannot get tenure, they cannot offer a wilderness experience in the wilderness settings that we are managing for (F5).

The above quote speaks to the difficulty that nature-based tourism operators have when trying to find suitable environments to conduct their activities. Certain landscapes in the province are managed in ways that are conducive to enjoyment of nature-based tourism activities. However, opportunities for commercial tourism operators to obtain tenure in these areas are limited. Therefore, many are forced to operate in landscapes that are primarily managed for timber harvesting. In these areas, the appearance of new forest industry impacts could negatively impact upon the experiences that nature-based tourism operators are trying to provide.

The interviews also revealed that there are systemic and long-standing issues that contribute to some of the conflict situations on Vancouver Island. Because timber production has such a high priority in British Columbia, it puts businesses that utilize forested areas for other purposes at a clear disadvantage. The influence that forestry has in the province was expressed by one forestry affiliated interviewee who stated:

The development of the forest industry in the early 1900s and the assumptions that kept happening until at least 1984 or so were very clearly skewed to developing the major economic driver of the province, which at that time was forestry. And we zoned literally all of the industry to forestry... Now we are talking about changing zoning in favour of tourism... All the government action regulation says is that if you are going to change the zoning, you have to have a better public outcome than the current zoning. While you are right that it puts a lot of power in the forest industry's hands, it is predicated on the fact that it [forestry] was king at one point (F7).

Despite the importance of forestry, tourism remains one of the most important economic drivers on Vancouver Island (Destination British Columbia 2014). However, forestry appears to receive priority when it comes to land-use decision-making. This is reflected in land-use objective regulations, which state that the Minister who is responsible for administering the Land Act must be satisfied that any amendment to land-use outweighs any adverse impact on timber harvesting opportunities (British Columbia Ministry of Agriculture and Lands 2008). Frustration with the priority given to timber production over other economic activities in the province was expressed by one tourism industry affiliated interviewee who said:

It [tourism] generates a lot of money and a lot of taxation. But the Ministry of Forests, Lands and Natural Resource Operations is still managing the forest and viewscapes like its 1965. Like forestry is 'where it's at.' (T9) It was also argued that some of the legislation governing natural resource management in British Columbia favours the forest industry. Some of this concern was directed towards the introduction of the Forest Range and Practices Act and the degree of power that it gives to the forest industry. When speaking about the Forest Practices Code that was replaced by the Forest Range and Practices Act in 2003, one tourism-affiliated individual raised concerns about the autonomy that the legislation gave the forestry industry:

With all the watering down of the Forest Practices Code and implementation of stewardship agreements with the companies, it is basically the fox looking after the henhouse. I think things have really gone backwards (T7).

Another underlying issue mentioned by one of the tourism industry-affiliated interviewees was the incomplete and out-of-date information used to develop visual quality objectives in certain areas. This can ultimately alter the ways in which forest practices are planned for and can affect the scenic values of areas used for nature-based tourism. Some deficiencies within the visual quality framework were also acknowledged by one of the forest industry-affiliated participants who stated:

I think there is room to improve them [visual quality objectives], to be sure, from a bunch of vantage points. How exactly and fitting them into the existing budget regime is another question (F7).

\section{Possible Solutions}

Despite the many ways in which forestry can negatively impact tourism on Vancouver Island, there are currently measures in place to help reduce the extent to which this occurs. For example, the Forest Range and Practices Act identifies visual quality and recreation as two of the eleven forest values to be managed on forested lands. It also includes provisions for the maintenance of visual quality and recreation values. In areas where visual quality is considered to be important, objectives are created to help maintain this value. (British Columbia Ministry of Forests 2001). Even though this system received some criticism from interview participants, it can still be credited with the preservation of certain viewscapes that have been maintained throughout Vancouver Island. In order to comply with this legal framework, forest companies that operate in visually sensitive areas are often required to dedicate a significant amount of effort and resources to help ensure developments are planned in a way that reduces the potential visual impact (British Columbia Ministry of Forests 2001).

As well as managing viewscapes, provisions are in place to facilitate communication and consultation between the forest industry and other stakeholders. This helps address potential concerns about forest industry impacts in certain areas. To ensure that consultation occurs, legal requirements have been put into place. For example, forest companies are required to publish notices in local newspapers when a forest stewardship plan is either created or amended so that they can receive feedback from stakeholders (Gooch 2013). This was explained by one forestry-affiliated interviewee, who stated:

When we advertise our forest stewardship plan or if we make certain types of amendments to our plan, the current legislative framework requires us to publish ads in the newspaper. It requires us to figure out who else operates on the land base... So, we need to figure out who 
holds tenures in the area and get a hold of them to let them know that we are either writing a plan, or advertising a plan, or amending a plan and we would like their input (F2).

In addition to legal tools, a number of forest companies take certain voluntary steps to communicate their plans to other stakeholders. According to one interview participant from the forestry industry, this is encouraged by the British Columbia Ministry of Forests, Lands and Natural Resource Operations:

We are trying to encourage licensees to develop relationships with tourism operators. And there is a role for us in facilitating that. Over the last couple of years, we have had a couple of workshops with licensees talking about their management practices in various areas. We encourage them to be proactive and build relationships with tourism operators and members of the public (F3).

Despite the measures that are already in place, suggestions about additional ways that conflicts between forestry and tourism could potentially be reduced were made by some of the interview participants. Although provisions are in place to encourage communication and consultation between the tourism and forest industries, some interviewees suggested that further improvements were still needed. Better communication between the two industries and a more proactive approach to management were identified as possible ways to improve the relationship between forestry and tourism.

I think more frequent dialogue would be beneficial and a more proactive approach would be beneficial. It is better than it was, but it is still not perfect. So, and this is just my opinion, if the forest industry and the Tourism Industry Association of BC were more frequently communicating with each other and proactively looking at what the future looks like as far as forest development and tourism development and how they impact each other, that would definitely improve things from where they are now (T6).

In addition to a more proactive approach to management, a suggestion was made to increase the degree of consultation required of forest companies when engaging with other licensees. In the opinion of some interview participants, the degree to which this occurs can vary considerably depending of the forest licensee. Certain aspects of the Forest and Range Practices Act were identified as being responsible for this variation in engagement. For example, one tourism-affiliated interviewee suggested that this piece of legislation was introduced to give the forest companies more flexibility, decrease the size of the forest management organization, and give the forest industry a higher degree of self-regulation (T9). These claims appear to be supported by publications that have been released by the British Columbia government (British Columbia 2005, Reader 2006). This participant also expressed concern that fewer mechanisms were in place to ensure that the concerns of stakeholders are addressed.

It was also suggested that the identification and special management of highly valued tourism areas could provide significant benefits to the tourism industry on Vancouver Island. Under the old Forest Practices Code, the Recreation Features Inventory was established to provide information about recreational features to resource managers in order to assist them when making land-use decisions. However, the most recent version of this document is over fifteen-years-old (British Columbia Ministry of Forests 1998), leading to questions about its relevance. High value tourism areas with special management regimes would not need to prohibit timber harvesting. Instead, forest management practices would place a higher priority on the needs of tourism, as opposed to what currently occurs in most parts of the province where forestry is prioritized (British Columbia Ministry of Agriculture and Lands 2008). When speaking about this, one of the tourismaffiliated interviewees stated:

There are places in British Columbia, especially along coastal $B C$, that are really exemplary. They are totally amazing places... So, we need to identify places of great tourism value like this... And we need to say, 'these have such incredible tourism values that we need be careful what we do here.' Many of them already have tourism industries that are active... Just give the industry something to work with and we can do amazing things. That minimal consideration, that minimal foresight on recognizing the exceptional places, is just not happening at all (T9).

Various tourism-affiliated interviewees expressed the opinion that a paradigm shift is needed in British Columbia with respect to forest management. While it has already been argued that the current legislative and management framework is skewed towards the needs of forestry in many ways, this ignores the fact that tourism is one of the most significant drivers of the British Columbia economy and much of that can be attributed to its promotion of the natural environment. When discussing this, one tourism-affiliated interviewee explained:

The larger structural thing, where the balance between tourism and industry issues needs to be a bit more equitable, is where we need to go in the long-term. So, recognize that wilderness tourism is a significant driver of the economy on the coast. In certain high value areas, it should be a priority to value tourism over extractive uses because it is more sustainable over the long-term (T4).

\section{Discussion}

The British Columbia Ministry of Forests, Lands and Natural Resource Operations has acknowledged that the Province's landscapes are one of the foundations of the tourism industry (British Columbia Ministry of Forests 2001). Additionally, the British Columbia Council of Tourism Associations has indicated that the health of the Province's tourism industry is tied to its natural beauty (Council of Tourism Associations 2007); the Province's own tourism marketing adopted the slogan "Super Natural British Columbia". However, the visual impacts associated with the forest industry and the ways in which this could negatively affect tourism was a topic that received significant attention from interviewees. This issue was recognized by individuals who work both in the forestry and tourism industries. Concerns about the effect of visual impacts on tourism appears to be validated in research that has documented negative perceptions relating to forest industry impacts amongst tourists (Hunt et al. 2000, British Columbia Ministry of Forests 2003, Hilsendager 2014).

Visual resource management is practiced throughout British Columbia to help address issues relating to the visual impacts that are commonly associated with forestry. Visual 
quality objectives are used to set visibility thresholds for landscape alterations (Picard and Sheppard 2001). These management objectives reflect the desired level of visual quality for a given area. Visual quality objectives are generally based on physical characteristics and social concerns for an area and establish the degree of visual alteration that can occur on a landscape. Any forestry activities that occur within a known scenic area that has established visual quality objectives must first complete a visual impact assessment before approval is granted, and this must be completed before any road construction or harvesting begins (British Columbia Ministry of Forests 2001). Although this process has produced some positive results, it could be argued that there is significant room for improvement. For example, a survey of landscapes across the province taken between 2007 and 2008 revealed that only $61 \%$ of those landscapes actually achieved the visual quality objectives that had been set. This number dropped significantly in areas considered to be highly sensitive (retention landscapes), where objectives were met only $33 \%$ of the time (Forest and Range Evaluation Program 2011). These figures suggest that many of the positive aspects of the visual quality objective system are outweighed by a lack of adherence to the required standards. Perhaps some type of enforcement program and a system that would penalize companies that do not meet legislated objectives could produce positive results for tourism

During the interviews, certain participants from the tourism and forestry industries expressed concern that the visual quality objectives in many areas of the province may be outdated. This could potentially put forestry into conflict with the needs of the nature-based tourism industry. An example of this can be seen along two of the more commonly travelled routes leading to one of British Columbias best-known multiday hikes on Vancouver Island. The journey to the start of the West Coast Trail from the Nanaimo ferries to Pachena Bay and Port Renfrew is dominated by clear-cuts visible along much of the roadside. With the West Coast Trail having gained a world-class reputation as a nature-based tourism attraction, it seems that these routes should be subject to stricter visual quality objectives. It could be argued that this may also be the case in certain areas of the Discovery Islands between Vancouver Island and mainland British Columbia. This region has become one of the most important marine tourism destinations in the province. However, the Discovery Islands Marine Tourism Group has voiced serious concerns about the effect that visual impacts from insensitive forestry practices are having on the nature-based tourism industry in this area (Hume 2012). Despite opposition from tourism operators, BC Timber Sales approved logging on Maurelle Island during the summer of 2013. According to members of the Discovery Islands Marine Tourism Group, most of their concerns were ignored during the consultation process leading up to this decision (Rudan 2013). These examples suggest that the needs of nature-based tourism are often ignored or overlooked-in favour of forestry-when it comes to visual resource management in certain areas of Vancouver Island.

Along with the visual impacts associated with forestry, other aspects of land use were identified by interviewees as having the potential to negatively impact the tourism industry. The fact that most areas of Vancouver Island are managed for timber production means that the tourism industry must operate alongside landscape-scale forest alterations. This was identified as a major concern in regions of Vancouver Island that are considered to have exceptional tourism value. Some interview participants indicated that their tourism businesses struggle to find acceptable environments to operate in when many landscapes are dominated by forest industry impacts. However, a large number of nature-based tourism operators have no choice but to operate in these highly altered landscapes because areas outside of protected areas that are specifically managed for the maintenance of tourism values are limited.

A contributing factor to the landscape-scale alterations created by forestry is the high priority that the industry receives when it comes to land-use planning. This was acknowledged by both tourism and forestry affiliated interview participants, some of whom stated that it is possible that this practice could potentially put other businesses that utilize forested landscapes (e.g., tourism) at a disadvantage. During the development of the forest industry in the early part of the twentieth century, most of British Columbia was zoned for timber production. In order to change zoning from an existing land use to something different, the Minister who is responsible for the Land Act must be satisfied that 'the importance of the land-use objective or amendment outweighs any adverse impact on opportunities for timber harvesting' (British Columbia Ministry of Agriculture and Lands 2008; p.13). This is in spite of the fact that forestry may or may not be the best land-use option for a given area (British Columbia Ministry of Forests 2003). It has been suggested that this policy is a result of the Provincial Government's fixation on the forest industry's traditional contribution to GDP (Gooch 2013), indicating a lack of willingness to adapt to the changing economic environment in British Columbia. However, tourism now plays a vital role in the British Columbia economy (BC Stats 2014b) and a high proportion of visitors list 'scenic beauty' as a primary motivation for visiting the province (Tourism Vancouver Island 2008). Therefore, it seems logical that tourism interests should be given a higher priority than what they currently receive when it comes to forest management decision-making. While current legislation positions forestry above tourism, this is based on the outmoded thinking that forestry is British Columbia's most important industry.

It appears that the priority given to forestry in British Columbia may have been exacerbated by the introduction of the Forest and Range Practices Act in 2004. The Forest and Range Practices Act was introduced (replacing the Forest Practices Code) as a means of reducing costs to government and industry and increasing flexibility for forest licensees (British Columbia 2005). It could be argued that the results-based approach gives priority to forestry interests at the expense of other forest users, removing much of the accountability from the forest companies, a view that was expressed by multiple tourism-affiliated interview participants. Despite increased costs, it seems that a regulatory framework surrounding forest resource management in British Columbia that is more equitable to all forest users would not only be fair, but also beneficial for all other industries that rely on the Province's forest resources, including nature-based tourism.

Another concern voiced by some interview participants relates to the lack of communication required by the forest industry when it comes to consultation with other stakehold- 
ers. Despite provisions in the Forest and Range Practices Act to help facilitate communication between forestry and other users, it appears that the level of communication required may not be adequate. This issue was raised during the interview process. However, it has also been mentioned by the Council of Tourism Associations in British Columbia (2007), that considers current consultation requirements to be inadequate. This seems to be supported by other studies that have also documented displeasure with public involvement processes surrounding forest management in British Columbia (Harshaw et al. 2009, British Columbia Forest Practices Board 2013).

According to the Forest and Range Practices Act, all forest licensees must develop a Forest Stewardship Plan; before a draft of the plan is submitted, they are required to abide by a mandatory period for public review. By publishing a notice in a newspaper, licensees have satisfied the requirement for public notice. However, there are currently no requirements for licensees to identify specific stakeholders who may be affected and to notify them of their plans. This does not appear to follow principles of effective consultation as defined by the British Columbia Forest Practices Board (Gooch 2013), which include early and effective communication that gives sufficient time for public involvement. According to the British Columbia Forest Practices Board (2003), the oversight body in the province, adequate resources should also be made available to the public to allow for effective participation that is inclusive, informative, accessible, and continuous. In addition, forest company responses to public input should be genuine and responsive. Based upon these principles of effective communication, the Forest Practices Board has criticized the level of consultation required by the Forest and Range Practices Act, stating that its requirements for public involvement in operational planning are minimal (British Columbia Forest Practices Board 2003). More stringent requirements for consultation could produce better results for other forest users, such as tourism operators. However, the Forest Stewardship Plan is the only plan that the public has a legislated right to review and provide comment on (British Columbia Forest Practices Board 2006). This is in spite of calls to allow greater opportunities for public input at all planning levels, from strategic to operational (British Columbia Forest Practices Board 2003).

According to some tourism-affiliated interview participants, it seems as though it is becoming increasingly difficult to find suitable areas to conduct nature-based tourism activities on Vancouver Island. Although the amount of private land in certain parts of Vancouver Island was identified by some as a contributing factor, visual impacts from forestry were also mentioned by multiple interview participants. It may be useful to identify additional areas within Vancouver Island that possess significant tourism values. These areas could be subjected to additional protection measures and special management regimes that could allow for some degree of timber harvesting, while prioritizing the needs of the tourism industry. It is possible that the importance of the nature-based tourism industry in the Discovery Islands, combined with current threats posed by logging, would make this region an ideal candidate for a management system like this.

Attempts that have been made in other jurisdictions to improve cooperation between forestry and tourism could inform British Columbia forest landscape planning. For example, the Ontario Ministry of Natural Resources (2001) developed a set of forest management guidelines to assist with the planning of forestry operations in areas that are important for tourism. These guidelines summarise management options to be considered when developing prescriptions in forest management plans which could affect nature-based tourism interests. Under the Crown Forest Sustainability Act (CFSA) of 1994, individuals responsible for preparing forest management plans are required to consult with these guidelines. This set of guidelines is also accompanied by a memorandum of understanding with the purpose of encouraging cooperation between the two industries (Ontario Ministry of Natural Resources 2006). Despite the presence of these provisions, critics within the tourism industry view them to be ineffective, due to a lack of proper implementation (Hunt et al. 2000).

In Tasmania, Australia, the Tourism and Forestry Protocol Agreement helps to manage the relationship between tourism and forestry in the state. This voluntary agreement was signed between Tourism Industry Council of Tasmania, Forestry Tasmania, Forest Industries Association of Tasmania, and Private Forests Tasmania (2009). Initially implemented in 2003, the purpose of this agreement is to help facilitate communication, consultation, and liaison between the forestry and tourism industries. This is done through meetings, briefings, stakeholder consultation, and information sharing. Within the agreement, a set of guidelines was developed to facilitate the process of conflict resolution for many of the common issues that arise between forestry and tourism (e.g., sightline planning, controlled burns, forestry access roads, transportation, branding, and education). Compliance requirements outline relevant rules, legislation, codes, and policies that are enforceable. Additional commitments that have been made by all parties to facilitate co-operation between forestry and tourism are also outlined in this document (TICT et al. 2009). Even though the agreement itself is not governed by any specific laws or acts, it does provide a useful tool to help improve communication and understanding between the tourism and forest industries, which is something that is often lacking in other regions where these two industries conflict.

Despite the importance of tourism and forestry to the British Columbia economy, few formal measures have been taken to facilitate cooperation between these two industries. In 1996, a voluntary agreement known as the Statement of Mutual Recognition and Respect was signed between the Council of Forest Industries, the Council of Tourism Asociations of British Columbia, and the Forest Alliance of British Columbia (1996). This one-page document is essentially a statement of mutual support and a pledge of cooperation from both industries. However, it does not have any legal power and does very little to provide specific direction about managing conflicting interests of forestry and tourism. Adopting a detailed set of guidelines for forest management in high value tourism areas could help to protect the natural landscapes that are so important to the British Columbia tourism industry. These guidelines could be accompanied by industry agreements that would help to facilitate consultation and cooperation between forestry and tourism. 


\section{Management Recommendations}

Based upon this research, a set of management recommendations has been developed to help guide jurisdictions that may be dealing with conflicts between nature-based tourism and forestry. Although each situation is unique, conflicts between these two industries often share many similarities. Therefore, the following principles may be used to help natural resource managers address issues which are similar to those that have been discussed in this research.

1) Stakeholders and decision-makers must recognize that both industries are important for the economic sustainability of a particular region. Assuming that both industries are important to a healthy economy, neither industry should get special consideration over the other when it comes to the management of forest resources.

2) Visual resource management is essential in destinations that promote natural attractions to help mitigate the visual impacts often associated with the forest industry. This may be achieved through the development and implementation of visual quality objectives where visual impact limits are set depending upon the level of sensitivity assigned to an area. Visual quality objectives should be regularly updated and based upon information that is accurate and up-to-date. To help ensure that these objectives are adhered to, visual management plans should be subject to an enforcement program with violators risking penalties.

3) Special legislation should be used to govern forests that are important for both forestry and nature-based tourism. These tools must:

a) Recognize the importance of both industries and contain prescriptions that ensure that the interests of one industry are not compromised by the other.

b) Provide a requirement that each industry is represented fairly. It is critical that legislation does not place a majority of the power into the hands of either the forest industry or the tourism industry.

c) Require that forest companies conduct sufficient research proving that their proposed operations will not negatively impact on the sustainability of surrounding businesses. This may include, but is not limited to, visual impact studies, economic impact analysis and, environmental impact assessments.

d) Ensure that tools are in place that require forest licensees to communicate and consult with other stakeholders before forest developments occur. Consultations should occur as early as possible and give sufficient time and opportunity for public involvement. Consultations should also be conducted in a way that is accessible to all interested stakeholders and continuous throughout the entire planning process.

4) Specific regions within nature-based tourism destination that possess significant tourism values need to be identified. These areas should be subjected to special management regimes that place a priority on nature-based tourism development. Any forest activity in these areas should be conducted in a way that is sensitive to needs of the tourism industry. This may be achieved through the establishment of protected areas networks that utilize a variety of the International Union for Conservation of Nature (IUCN) -protected area categories and special management zones to achieve desired results.
5) Formal agreements between forest industry partners and all relevant stakeholders within the tourism industry can be useful tools for improving the relationship between the tourism and forest industries. This may be accompanied by a document(s) that provides a framework to help facilitate consultation and cooperation between the two industries.

6) A negative public perception of a region's forest industry has the potential to negatively impact upon both forestry and tourism in destinations that rely on natural landscapes. Therefore, the forest industry should make genuine attempts to maintain a positive public image. This could likely be achieved if the industry is reactive to concerns raised by members of the public. These concerns may include, but are not limited to, the harvesting of oldgrowth forests, sustainability of management practices, and visual impacts associated with the industry.

\section{Conclusion}

Both forestry and tourism play important roles in the British Columbia economy. However, the viability of the tourism industry relies heavily upon the maintenance of the province's natural landscapes. During the 2013 provincial election, a key platform used by the incumbent BC Liberal Party was a 'jobs plan', with the primary objectives being job creation and the expansion of markets for British Columbia products and services (British Columbia 2012). As part of this plan, the Provincial Government released a five-year tourism strategy intended to help guide government, industry, stakeholders, and communities in working together to deliver the best results for the tourism industry. One of the key objectives of the five-year strategy was to achieve 5\% growth per year within the British Columbia tourism industry. This plan acknowledged that outdoor adventure experiences in pristine natural settings are critical to tourism experiences within the province and 'intrinsic to the Super Natural British Columbia brand' (British Columbia Ministry of Jobs, Tourism and Innovation 2012; p. 31). However, evidence presented in this research indicates that forestry has the potential to negatively impact nature-based tourism if forest practices are not sensitive to the needs of the tourism industry. It also appears that forestry receives a higher priority than tourism in many regions of Vancouver Island, an important tourist destination. This is in spite of the vital importance of tourism to the British Columbia economy, both currently and in the future. It seems as though a forest industry that is more sensitive to the needs of nature-based tourism would help to facilitate the Provincial Government's goal of 5\% growth in the tourism industry per year.

It is not uncommon for nature-based tourism destinations to rely on the same resources as the forest industry. Not surprisingly, the fundamental differences in desires for forest use between these two industries can often lead to conflict situations. In jurisdictions that rely heavily on both industries, it is in the best interest of governments to ensure that the actions of one industry do not impact upon the viability of the other. Therefore, it is desirable to manage these two industries in a way that minimizes the potential for resource-use conflicts. For natural resource managers who are dealing with conflicts between nature-based tourism and forestry, consideration of the principles discussed in this research could help to provide solutions that maximize benefits for both industries. 


\section{References}

BC Stats. 2014a. BC Tourism and High Technology GDP and Employment [online]. Available from http://www.bcstats. gov.bc.ca/StatisticsBySubject/Economy/EconomicAccounts/ SatelliteAccounts.aspx [accessed 27 October 2015].

BC Stats. 2014b. Tourism Indicators 2012. Province of British Columbia.

BC Stats. 2015a. BC GDP by Industry - NAICS Aggregations, 19972014 [online]. Available from http://www.bcstats.gov.bc.ca/StatisticsBySubject/Economy/EconomicAccounts.aspx [accessed 27 October 2015].

BC Stats. 2015b. Employment and Unemployment Rates by Detailed NAICS Industry and Development Region, Vancouver Island/Coast [online]. Available from http://www.bcstats. gov.bc.ca/StatisticsBySubject/BusinessIndustry/BusinessCountsEmploymentByIndustry.aspx [accessed 15 April 2015].

British Columbia. 2000. Vancouver Island Summary Land Use Plan. Government of British Columbia.

British Columbia. 2005. FRPA Training Companion Guide: Version 2.3. Government of British Columbia.

British Columbia. 2012. Canada Starts Here: The BC Jobs Plan. Government of British Columbia.

British Columbia Forest Practices Board. 2003. Opportunity for Public Consultation Under FRPA - Bulletin 003. Victoria, BC: Forest Practices Board.

British Columbia Forest Practices Board. 2006. A Review of the Early Forest Stewardship Plans Under FRPA. Victoria, BC: Forest Practices Board.

British Columbia Forest Practices Board. 2013. Public Involvement in Forest Management Planning in BC. (Board Bulletin, Volume 15). Victoria, BC: Forest Practices Board.

British Columbia Ministry of Agriculture and Lands. 2008. Land Use Objectives Regulation: Policy and Procedures. Victoria, BC: Strategic Land Policy and Legislation Branch and Integrated Land Management Bureau.

British Columbia Ministry of Forests. 1998. Recreation Features Inventory: Procedures and Standards Manual. Victoria, BC: Forest Practices Branch.

British Columbia Ministry of Forests. 2001. Visual Impact Assessment Guidebook (2nd ed.). Victoria, BC: Forest Practices Branch.

British Columbia Ministry of Forests. 2003. Economic Benefits of Managing Forestry and Tourism at Nimmo Bay: A Public Perception Study and Economic Analysis. Victoria, BC: Forest Practices Branch and Economics Trade Branch.

British Columbia Ministry of Forests and Range. 2006. The Public Response to Harvest Practices in British Columbia at the Landscape and Stand Level. Victoria, BC: Forest Practices Branch.

British Columbia Ministry of Forests, Lands and Natural Resource Operations. 2012. Timber Tenures in British Columbia: Managing Public Forests in the Public Interest. Victoria, BC: Forest Tenures Branch.

British Columbia Ministry of Forests, Lands and Natural Resource Operations. 2015. Land Use Operational Policy: Adventure Tourism. Victoria, BC: Land Tenures Branch.

British Columbia Ministry of Jobs, Tourism and Innovation. 2012. Gaining the Edge: A Five-year Strategy for Tourism in British Columbia 2012-2016. Government of British Columbia.

Buckman, G. 2008. Tasmania's Wilderness Battles: A History. Allen \& Unwin, Crows Nest, Australia.

Cashore, B., G. Hoberg, M. Howlett, J. Rayner and J. Wilson. 2001. In Search of Sustainability: British Columbia Forest Policy in the 1990's. UBC Press, Vancouver, BC.

Council of Forest Industries, Council of Tourism Associations of British Columbia \& Forest Alliance of British Columbia. 1996. Statement of Mutual Recognition and Respect. COFI, COTABC, FABC, British Columbia
Council of Tourism Associations. 2007. A Tourism Industry Strategy for Forests. COTA, British Columbia

Destination British Columbia. 2014. The Value of Tourism in British Columbia: Trends from 2002 to 2012. Tourism BC, British Columbia.

Environmental News Network. 2006. Global Outcry Over Falling Forests and Failing Democracy on Australia's Island State of Tasmania [online]. Environmental News Network. Available from http://www.enn.com/press_releases/1113 [accessed 26 July 2015].

Ford, R.M., K.J.H. Williams, E.L. Smith and I.D. Bishop. 2012. Beauty, belief, and trust: Toward a model of psychological processes in public acceptance of forest management. Environment and Behavior. 46(4): 476-506. doi: 10.1177/0013916512456023

Forest and Range Evaluation Program. 2011. Chief Forester's 2010 Annual Report on the Forest and Range Evaluation Program. British Columbia: Forest and Range Evaluation Program.

Gooch, N. 2013. Tourism and forestry tenure on crown land: A time for change. Appeal. 18: 37-54. Available from http://journals. uvic.ca/index.php/appeal/article/viewFile/12116/3606 [accessed 26 July 2015].

Hanna, K.S., R.W. Negrave, B. Kutas and D. Jojkic. 2008. Conflict and protected areas establishment: British Columbia’s political parks. In K.S. Hanna, D.A. Clark \& D.S. Slocombe (eds.). Transforming Parks and Protected Areas: Policy and Governance in a Changing World. pp. 137-153. Routledge, NY

Harshaw, H.W., S.R.J. Sheppard and P. Jeakins, P. 2009. Public attitudes toward sustainable forest management: Opinions from forest dependent communities in British Columbia. BC J. Ecosyst. Manage. 10(2): 81-103. Available from http://jem.forrex.org/forrex/ index.php/jem/article/view/422/337 [accessed 26 July 2015]

Hilsendager, K.W. 2014. Tourists' Visual Perceptions of Forests and Forest Management in British Columbia and Tasmania. Ph.D. thesis, Faculty of Graduate and Postdoctoral Studies, The University of British Columbia, Vancouver, BC

Hume, M. 2012. Tourism in the Discovery Islands feels the force of logging. [online]. The Globe and Mail. Available at http://www.theglobeandmail.com/news/british-columbia/tourism-in-the-discovery-islands-feels-the-force-of-logging/article9703141 [accessed 27 July 2013].

Hunt, L., W. Haider and M. Johnson. 2000. Ontario Resource Based Tourism Operators and Forest Management: Highlights of an Operator Survey. Ontario Ministry of Natural Resources, Centre for Northern Forest Ecosystem Research. Thunder Bay, ON

Kearney, A.R. 2001. Effects of an informational intervention on public reactions to clear-cutting. Society and Natural Resources. 14: 777-790. doi:10.1080/089419201753210594

Kraus, R. and L. Allen. 1997. Research \& Evaluation in Recreation, Parks \& Leisure Studies $2^{\text {nd }}$ ed. Gorsuch Scarisbrook Publishers, Scottsdale, AZ

Magnusson, W. and K. Shaw. 2002. A Political Space: Reading the Global through Clayoquot Sound. McGill-Queens University Press, Montreal, QC

Malkinson, L. 2011. A Preliminary Evaluation of the Results-Based Forest and Range Practices Act: Fostering Innovation in Forest Practices? M.Sc. thesis, Faculty of Graduate and Postdoctoral Studies, The University of British Columbia, Vancouver, BC

McCool, S.F., R.E. Benson and J.L. Ashor. 1986. How the public perceives the visual effects of timber harvesting: an evaluation of interest group preferences. Environ. Manage. 10(3): 385-391. Available at http://link.springer.com/article/10.1007\%2FBF01867264 [accessed 26 July 2015]

McKercher, B. 1992. Tourism as a conflicting land use. Ann. Tourism Res. 19: 467-481. doi:10.1016/0160-7383(92)90131-8

Ontario Ministry of Natural Resources. 2001. Management Guidelines for Forestry and Resource-Based Tourism. Forest Management Branch, Toronto, ON 
Ontario Ministry of Natural Resources. 2006. Tourism and Forestry Memorandum of Understanding. Ontario Government, Toronto, ON

Picard, P. and S. Sheppard. 2001. The effects of visual resource management on timber availability: a review of case studies and policy. BC J. Ecosy. Manage. 1(2): 1-12. Available at http://www. researchgate.net/publication/228799268_The_effects_of_visual_res ource_management_on_timber_availability_A_review_of_case_stu dies_and_policy [accessed 26 July 2015]

Reader, R. 2006. The Expectations that Affect the Management of Public Forest and Range Lands in British Columbia: Looking Outside the Legislation. Government of British Columbia.

Ribe, R.G. 2004. Aesthetic perceptions of green-tree retention harvests in vista views: the interaction of cut level, retention patterns and harvest shape. Landscape Urban Plan. 73: 277-293. doi:10.1016/j.landurbplan.2004.07.003

Ribe, R.G. 2006. Perceptions of forestry alternatives in the US Pacific Northwest: information effects and acceptability distribution analysis. J. Environ. Psychol. 26:100-115. doi: 10.1016/j.jenvp. 2006.05.004

Rudan, P. 2013. Maurelle Island logging to proceed in spite of opposition. [online]. Campbell River Mirror. Available at http://www. campbellrivermirror.com/news/214026781.html [accessed 27 July 2013].

Shindler, B.A., M. Brunson and G.H. Stankey. 2002. Social Acceptability of Forest Conditions and Management Practices: A Problem Analysis. United States Department of Agriculture, Portland, OR.
Tourism Industry Council of Tasmania. 2007. Pulp Mill Tourism Operators Research Report. Enterprise Research and Marketing Services, Moonah, Australia.

Tourism Industry Council of Tasmania, Forestry Tasmania, Forest Industries Association of Tasmania and Private Forests Tasmania. 2009. Tourism \& Forestry Protocol Agreement: A Code of Mutual Understanding. TICT, FT, FIAT \& PFT, Tasmania, Australia. Tourism Vancouver Island. 2008. Vancouver Island Exit Survey. Industry Services Department, Nanaimo, BC.

Tourism Vancouver Island. 2011. Vancouver Island Outdoor Guide. Page One Publishing, Victoria, BC.

Tyrvainen, L., M. Uusitalo, H. Silvennoinen and E. Hasu. 2014. Towards sustainable growth in nature-based tourism destinations: Clients views on land use options in Finnish Lapland. Landscape Urban Plan. 122: 1-15. doi:10.1016/j.landurbplan.2013.10.003

Wagner, R.G., J. Flynn, R. Gregory, C.K. Mertz and P. Slovic. 1998. Acceptable practices in Ontario's forests: differences between public and forestry professionals. New Forests. 16: 139-154. doi:10.1023/A:1006577019706

Wilson, J. 1998. Talk and Log: Wilderness Politics in British Columbia. UBC Press, Vancouver, BC 